・论坛・ 中国国家公园试点专题

\title{
祁连山国家公园体制试点经验
}

金芘*

中国林业科学研究院自然保护地研究所, 北京 100091

金峘 (2021) 祁连山国家公园体制试点经验. 生物多样性, 29, 298-300. doi: 10.17520/biods.2021046.

Jin K (2021) On the experiences of Qilian Mountain National Park system pilot. Biodiversity Science, 29, 298-300. doi: 10.17520/biods.2021046.

\section{On the experiences of Qilian Mountain National Park system pilot}

Kun Jin ${ }^{*}$

Research Institute of Natural Protected Area, Chinese Academy of Forestry, Beijing 100091

祁连山国家公园地跨甘肃、青海两省, 总面积 $50,237 \mathrm{~km}^{2}$ ，其中，甘肃片区面积占68.5\%，青海片 区面积占31.5\%。祁连山国家公园所在的祁连山是 国家重点生态功能区之一, 承担着维护青藏高原生 态平衡, 阻止腾格里、巴丹吉林和库姆塔格三大沙 漠南侵, 保障黄河和河西内陆河径流补给的重任。 祁连山是我国生物多样性保护优先区之一, 是世界 高寒种质资源库, 是野牦牛(Bos mutus)、白唇鹿 (Przewalskium albirostris)、藏野驴(Equus kiang)、马 噟(Moschus chrysogaster)、黑颈鹤(Grus nigricollis)、 冬虫夏草 (Cordyceps sinensis)、雪莲 (Saussurea involucrata) 等珍稀濒危物种的重要栖息地, 特别是 世界生物多样性保护的旗舰物种——雪豹 (Panthera uncia)的重要栖息地。祁连山国家公园的 建立, 对于保障祁连山生态系统的原真性和完整性, 保障河西走廊乃至西部地区的生态安全具有重大 战略意义。2017年9月1日，中共中央办公厅、国务 院办公厅印发了《祁连山国家公园体制试点方案》。 祁连山国家公园体制试点开展以来, 通过建立分级 统一的管理体制, 创新运行机制, 国家公园建设稳 步推进, 生态成效和社会效益渐显。笔者参加了国
家公园体制试点相关工作, 对祁连山国家公园体制 试点取得的一些可借鉴和推广的经验进行探讨。

\section{管理体制创新}

形成了中央与地方共同管理模式。依托国家林 业和草原局驻西安森林资源监督专员办事处组建 祁连山国家公园管理局, 在甘肃、青海两省林业和 草原局加挂省级管理局牌子, 由国家林业和草原局 与省政府双重领导, 以省政府为主(蔵振华等, 2020)。祁连山国家公园管理局于2018年10月29日在 兰州揭牌, 为正厅级行政单位。2018年11月1日, 祁 连山国家公园甘肃省管理局在兰州挂牌。2018年11 月30日, 祁连山国家公园青海省管理局在西宁挂 牌。甘肃省片区建立了省管理局、管理分局、保护 站三级垂直管理体系, 组建了祁连山国家公园甘肃 省管理局酒泉分局、张掖分局, 酒泉分局下设6个保 护站，张掖分局下设 22 个保护站。祁连山国家公园 青海省管理局下设祁连山国家公园青海省管理局 办公室和祁连山国家公园青海服务保障中心, 以及 德令哈、天峻、祁连、门源四县市管理分局, 建立 9 个管护中心和 40 个管护站点。 


\section{省委书记和省长任双组长推动运行}

2017年12月8日，原国家林业局会同甘肃、青海 两省建立了祁连山国家公园“三方会商”机制。国家 林业和草原局与甘肃、青海两省政府成立了协调工 作领导小组, 在祁连山国家公园管理局设立办公 室。甘肃省委省政府成立由省委书记、省长任双组 长的“甘肃省祁连山国家公园体制试点领导小组”, 全面负责甘肃省祁连山国家公园体制试点工作, 研 究解决重大问题。同时省政府成立协调推进组, 省 政府常务副省长任组长, 分管副省长任副组长, 办 公室设在省林业和草原局。青海省委省政府成立了 由省委书记、省长任双组长的祁连山国家公园体制 试点工作领导小组, 领导小组办公室设在省林业和 草原局。确保了体制试点任务责任靠实、推进得力。

\section{3 多种方式健全矿业权退出新机制}

甘肃省片区按照“共性问题统一尺度、个性问 题一矿一策” 的思路, 引导矿权分类实施、有效退出, 祁连山国家公园甘肃省片区生态环境问题整改涉 及的所有矿业权, 已采取注销式、扣除式、补偿式 共3种方式全部退出, 并采取封堵探洞、回填矿坑、 拆除建筑物以及种草植树等综合措施恢复生态环 境。与祁连山国家公园范围存在重叠的矿业权, 根 据矿业权的不同情况采取以下方式分类处置: (1)注 销退出。主要是针对矿业权人自愿放弃的探矿权和 采矿权, 由市县政府督促矿业权人向原发证机关申 请注销。(2)扣除退出。对矿业权与自然保护地部分 重叠的, 采取扣减重叠部分避让自然保护地的方式 退出。剩余区域必须符合矿业权延续变更条件。(3) 补偿退出。对采取注销、扣除方式处置之外的探矿 权和采矿权, 统筹考虑矿业权历史与现状, 酶情以 补偿方式退出。市县政府是筹集补偿资金的责任主 体。

\section{构建生态保护与民生改善协调发展的新槙}

为确保国家公园核心保护区农牧民自觉自愿 搬得出、稳得住、收入有保障、生活有改善、发展 有前景，甘肃省张掖市采取“四个一”的措施引导农
牧民易地搬迁、转产增收。(1)每户确定一名护林员; (2)每户培训一名实用技能人员; (3)每户扶持一项持 续增收项目; (4)确保每户享受到一整套惠民政策。 青海省片区建立 “村两委+社区参与”共建共管共享 工作机制。“村两委+社区参与”共建共管共享机制 是以国家公园内社区村两委为依托, 以社区群众为 主体, 建立巡护、宣传两支队伍, 推动生态保护效 益加快转化成社区发展和民生效益, 积极探索生态 保护与民生改善协调发展的新路径。

\section{推动实现生态保护管理新方式}

甘肃省片区运用卫星遥感、天空地一体化、对 地观测、地面监测等信息技术, 在张掖市率先建成 “一库八网三平台”生态保护信息监控系统和智慧水 务监控系统。青海省片区着力构建九大支撑体系, 不断增强国家公园生态保护管理综合能力, 包括推 动规划体系建设、构建科研监测体系、社会参与体 系、保护管理体系、自然教育体系、基础保障体系、 信息化管控体系、志愿服务体系和教育培训体系。 青海省片区建立综合执法机制。建立协调统一、分 工明确的国家公园生态监管体系, 主要是整合海西 州、海北州两州政府以及省直有关部门执法力量, 全面组织开展国家公园综合执法和专项督查检查 行动, 构建综合执法长效机制。青海省祁连县人民 法院成立了祁连山生态法庭, 有利于试点片区内生 态环境资源的司法保护。

\section{6 打造开放共享的科技支撑平台}

甘肃省片区搭建学术交流平台和合作发展平 台, 吸引国内外高校和科研机构为国家公园建设发 展提供技术服务。甘肃省片区在全国率先成立祁连 山国家公园(甘肃片区)科技创新联盟, 整合省内外 20 余个科研院所、高校、相关企业等部门和领域的 科技资源优势, 围绕重大科学问题, 开展学术研讨 交流, 谋划科技攻关方向, 确定研究课题架构, 联 合申报科技计划项目。

致谢: 感谢国家林业和草原局国家公园管理办公室, 中国科学院生态环境研究中心欧阳志云研究员、卫 
伟研究员、孔令桥助理研究员, 国家林业和草原局 经济发展研究中心李冰教授级高级工程师、赵金成 教授级高级工程师、陈雅如高级工程师、李想高级 工程师，祁连山国家公园管理局，祁连山国家公园 甘肃省管理局, 祁连山国家公园青海省管理局等提 供支持。部分内容参考了《祁连山国家公园体制试 点评估验收报告》，在此一并致谢。

\section{参考文献}

Zang ZH, Zhang D, Wang N, Du A, Kong LQ, Xu WH, Ouyang ZY (2020) Experiences, achievement, problems and recommendations of the first batch of China's national park system pilots. Acta Ecologica Sinica, 40, 8839-8850. (in Chinese with English abstract) [藏振华, 张多, 王楠, 杜傲, 孔令桥, 徐卫华, 欧阳志云 (2020) 中国首批国家公园体 制试点的经验与成效、问题与建议. 生态学报, 40, 8839-8850.]

(责任编委：徐卫华 责任编辑：时意专) 